\title{
The Application of Business Impact Analysis Due to Electricity Disruption in a Container Terminal
}

\author{
Eko Hariyadi Budiyanto *, Raja Oloan Saut Gurning and Trika Pitana \\ Faculty of Marine Technology, Institut Teknologi Sepuluh Nopember, Surabaya 60111, Indonesia; \\ sautg@its.ac.id (R.O.S.G.); trika@its.ac.id (T.P.) \\ * Correspondence: ekobudiyanto.17041@mhs.its.ac.id
}

Citation: Budiyanto, E.H.; Gurning, R.O.S.; Pitana, T. The Application of Business Impact Analysis Due to Electricity Disruption in a Container Terminal. Sustainability 2021, 13, 12038. https://doi.org/10.3390/ su132112038

Academic Editor: Paul Tae-Woo Lee

Received: 5 September 2021

Accepted: 27 October 2021

Published: 31 October 2021

Publisher's Note: MDPI stays neutral with regard to jurisdictional claims in published maps and institutional affiliations.

Copyright: (c) 2021 by the authors. Licensee MDPI, Basel, Switzerland. This article is an open access article distributed under the terms and conditions of the Creative Commons Attribution (CC BY) license (https:/ / creativecommons.org/licenses/by/ $4.0 /)$.
Abstract: A container terminal is a facility used to collect containers from the hinterland and ports for distribution to the end destination. Based on these essential functions, container terminals often reflect the economic conditions in a country. Many studies have recently examined the use of business impact analysis (BIA) when disruption happens at a container terminal. In sustainability and business impact research, the economy is one of the prioritized aspects of impact analysis. The impact related to the economic aspect is generally caused by disruptions resulting from natural disasters, pandemics, and human activities (terrorists, labor issues, and lockouts). Until this article was conducted, there was still little literature explaining the business impact analysis procedures with case studies of disruptions in container terminals related to operational constraints. This paper aims to provide a perspective in deepening and adapting the BIA procedure initially general into an analysis that can be applied to the container terminal business. This paper takes a case study of BIA in a container terminal caused by electrical disruption. Based on the research, six categories of disruption became a concern when the port's electricity supply stopped, i.e., decreased productivity, economic loss, reduced employee productivity, decreased numbers of customers, a decline in company reputation, and wasted energy.

Keywords: business impact analysis; business continuity management; container terminal; risk assessment; maritime sector; electrical disruption

\section{Introduction}

In practice, the maritime sector's risk and continuity assessment process, especially container terminal services, requires in-depth analysis [1]. The analytic complexity is due to the relationship between the container terminal business process and its operational side. Henesey (2003) states that container terminals are viewed as complex systems with many interrelated elements and uncertainties.

Resilience is an element that has a close relationship in analyzing business risks and impacts on a container terminal [2]. The existence of resilience is due to the fact that disruption to the container terminal can severely impact the profits and reputation of the container terminal service provider and hamper the distribution process from the ship to the end destination. Disruption events at the container terminal are events that cannot be predicted with certainty. Several conditions can cause a container terminal to not operate as usual, such as natural disasters, technical problems, human error, and the combination of several states. Therefore, the disruption in the container terminal is a type of uncertainty condition [3]. With these two elements in the container terminal business, to maintain and plan for business continuity, the risk analysis process should also be complemented by a business impact analysis so that business continuity planning can be specific, measurable, achievable, and relevant.

Containers have become an essential part of shipping in the world of international sea transportation [4]. The increasing number of container terminals will create a competition 
space for every business in this industry. Their growing use encourages efficiency, effectiveness, and the application of the latest technology so that services can be more optimal, reduce costs to the greatest degree possible, and ensure continuity of service. Disruption management-based operation planning is essential to optimize container services at the container terminal [5]. Transportation disruption could cause economic losses due to the cessation of the supply chain system [6].

The electrical system is one of the essential aspects of container terminals because all activities carried out in the container terminal need to be supported by electrical power [7]. In addition to ensuring that every part of electrical equipment has a good quality, it is also necessary to ensure the continuity of the power distribution system to the container terminal. According to Ghiasi (2019), minimizing electrical system failures can increase reliability, and thus, optimize operations [8]. Mai's research supports this position (2018); in general, heavy industry relies on electricity to carry out its activities, and therefore, the electrical system is one of its principal parts [9].

To measure how an electrical disruption impacts the Container Terminal business, a methodology is needed to analyze the disruption as an impact on a certain scale. With a measure on a certain scale, the impact can be justified in terms of whether it is on a low scale or on a large scale that can disrupt the running of the business. The methodology currently under development for the analysis of impacts is known as business impact analysis, which is also part of the business continuity management system, and is included in the ISO 22301:2019 and ISO 22317:2015 standards. Through the ISO standard, business impact analysis is explained in general regarding how the analysis is carried out, starting from defining the type and impact criteria to determine the organization's dependencies on these impacts. To run a business impact analysis in the maritime sector, especially in container terminals, business impact analysis materials need to be deepened and adapted to the business characteristics. These characteristics include work patterns, activity outputs, targets to be achieved, operational procedures, and the unique relationship of the machinery and equipment used in the industry with terminal performance.

This study explored how a disruption can be analyzed using a business impact analysis (BIA) approach. The disruption used as an example in this study is a BIA approach adopted due to electrical disruption in a container terminal. Electrical disruption is considered a disruption that can stop container loading and unloading service activities at the port.

\section{Literature Review}

Business impact analysis (BIA) is a tool for impact analysis at the management level. An organization assesses the impact of quantitative and qualitative losses if the organization experiences a business continuity emergency, incident, or crisis [10]. The results of the $\mathrm{BIA}$ are used to make a decision related to business continuity management strategies and solutions [11,12]. The relationship between BIA, organizational goals, BCM strategy, and risk assessment is shown in Figure 1. 


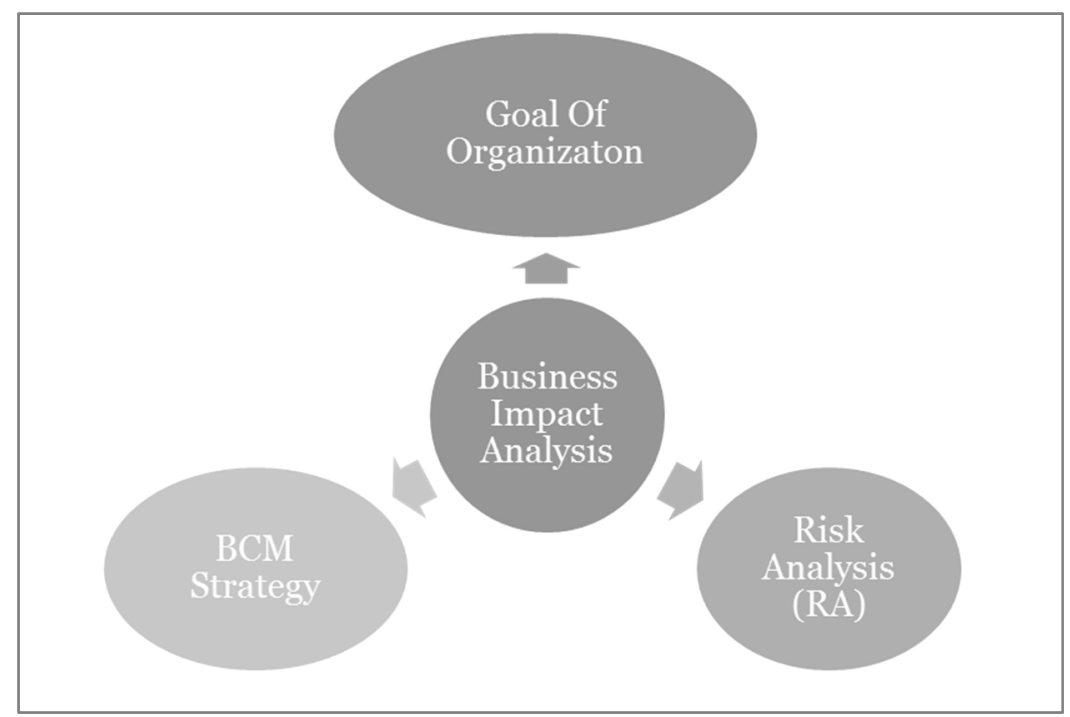

Figure 1. Relationship between BIA with the Organization's goal, BCM, and Risk Analysis [13].

Research on business impact analysis, with seaports as a case study, has been carried out by several researchers. Chang (2000) wrote about the impact analysis of Kobe Port following the 1995 earthquake. This study was exploratory, explaining some of the impacts experienced by Kobe Port, as well as the recovery processes initiated afterwards, such as the economic impact and domestic cargo traffic activities, and the impact of overseas containers (transshipment) [14].

In 2002, the same writer, Chang, in collaboration with Falit-Baiamonte, again wrote about the impact of natural disasters, namely the earthquake in Nisqually. This study focuses on several business sectors, buildings, and employees in the area [15]. In the same year, 2002, Cohen conducted a study on the impacts of the West Coast Dock Shut Down. As a result of this lockdown, cargo ships could not dock. Several sectors of the manufacturing, retail, and agricultural industries experienced a slowdown in the production and delivery of spare parts, which had implications in the form of economic impacts on the United States and the countries connected to it [16].

In 2004, terror incidents at seaports and airports became an issue in California. Therefore, analysis related to preventive measures that can be taken to reduce the risk of terror was carried out; however, the impact of a terrorist attack was not discussed [17].

In 2011, Hirai conducted a study on the port's functionality and business continuity against the Japanese earthquake of the same year. Research on BIA concerns the economic impact and production disruption caused by natural disasters [18]. Ono then conducted research using the same case study by developing the BCM framework [19].

In 2012, Omer conducted a study to develop a framework for assessing the resilience of the maritime transportation system. Resilience is the ability of an organization to rise and recover after a disruption. The resilience of a port can be measured by cargo tonnage, delivery time, and cost [20].

In 2013, Rose and Wei conducted simulations and estimates of the economic consequences caused by the cessation of port activities of The Port Arthur/Beaumont Metropoli$\tan$ Statistical Area, which was simulated for 90 days. The economic impact data used in this article were obtained from secondary data. This article did not explain what disruption occurred and how the impact was calculated following the disruption [21].

In 2015, Novati researched the modeling of the effects of disruption on ports using the costs of container distribution disruption due to seismic and conflict hazards [22]. In the same year, Wijaya developed a financial management process framework that uses BIA as one of its processes. BIA is carried out through meetings between branch and head offices to increase communication via information technology [23]. 
In 2016, Benavente conducted joint research with Ono to develop a methodology and procedure for determining BIA to improve business continuity for ports. This research was conducted by using Chile as a case study on the disruption caused by an earthquake. BIA can be applied via a qualitative screening system with an output in the form of the MTPD (Maximum Tolerable Period of Destruction) [24]. In addition, in 2016, Oztanriseven and Nachtmann simulated the economic impact of the disruption on the McClellan-Kerr Arkansas River navigation system connecting the United States with the rest of the world via the Mississippi River and the Port of New Orleans. Disruption was carried out on a time basis, i.e., short term (10 days), medium-term (60 days), and long term (180 days) [25].

In 2021, Notteboom conducted research and data collection on the economic impact caused by the COVID-19 pandemic. The process of collecting data was undertaken using a survey method. Between early April and mid-July 2020, between 40\% and more than $50 \%$ of all respondents indicated that container ship calls fell by more than $5 \%$. However, in September 2020 (week 36), the situation improved significantly and reached a lower $28 \%[26]$.

Based on the literature search, it is known that, up to now, the business impact analysis approach carried out for ports has prioritized economic aspects, with the causes of disruption being in the form of natural disasters, human activities (terrorists, labor disruptions, and lockouts), as well as the existence of a pandemic. Until the research underpinning this article was conducted, there was still a paucity of literature explaining business impact analysis procedures through the use of case studies of disruptions in container terminals related to operational constraints with quantitative calculations. Therefore, as a scientific contribution, this article explores how business impact analysis can be adapted to the maritime business, especially in container terminals. This study uses quantitative and qualitative approaches, involving container terminal management as part of the analysis and utilizing the terminal's historical performance data when a disruption occurs in comparison to data representing normal conditions.

\section{Research Method}

The research method in this article consists of three parts. The first part explains the scope and procedures of business impact analysis, and specifically, demonstrates how business impact analysis is deepened with a maritime business case study. The second part includes a method for defining impact categories in a disruption case study. The third part contains a quantitative method for assessing an impact based on its impact category.

\subsection{Scope and Procedure of BIA}

Exploration was carried out at Container Terminal $X$ in Surabaya, Indonesia, as a case study. The research began by identifying the causes and impact of the electricity supply disruption at the container terminal. The data used in this paper were from primary data obtained from container terminal and secondary data obtained from journals and research related to electricity supply disruption and its impact.

These impacts can occur when an organization is exposed to a disruptive incident. BIA will produce a measurement of the incidents encountered to make decisions related to strategies in dealing with disruption.

In general, BIA procedures can be adopted from the ISO 22317:2015 Guidelines for business impact analysis. ISO 22317:2015 contains guidelines for the BIA process to be carried out step by step, starting from identifying the scope and role and later clarifying position of the BIA after obtaining approval from management. Because it is still general, the BIA listed in ISO 22317:2015 requires further details in order to be applied to the maritime industry, especially in container terminals. Adaptation to the BIA needs to consider matters relating to the operational performance of the container terminal. The operational performance includes the company's vision and mission, loading and unloading work patterns, activity outputs, performance targets, machinery that affects business activities, resources used, business reputation, and emission characteristics that need to be minimized. 
To satisfy the demand for BIA application in container terminals and as a form of scientific contribution, in this article, we explore and adapt BIA material to maritime business aspects, especially in its application to container terminals due to operational disruption. Figure 2. shows the BIA material, which is deepened and adapted to the business and activities in the container terminal.

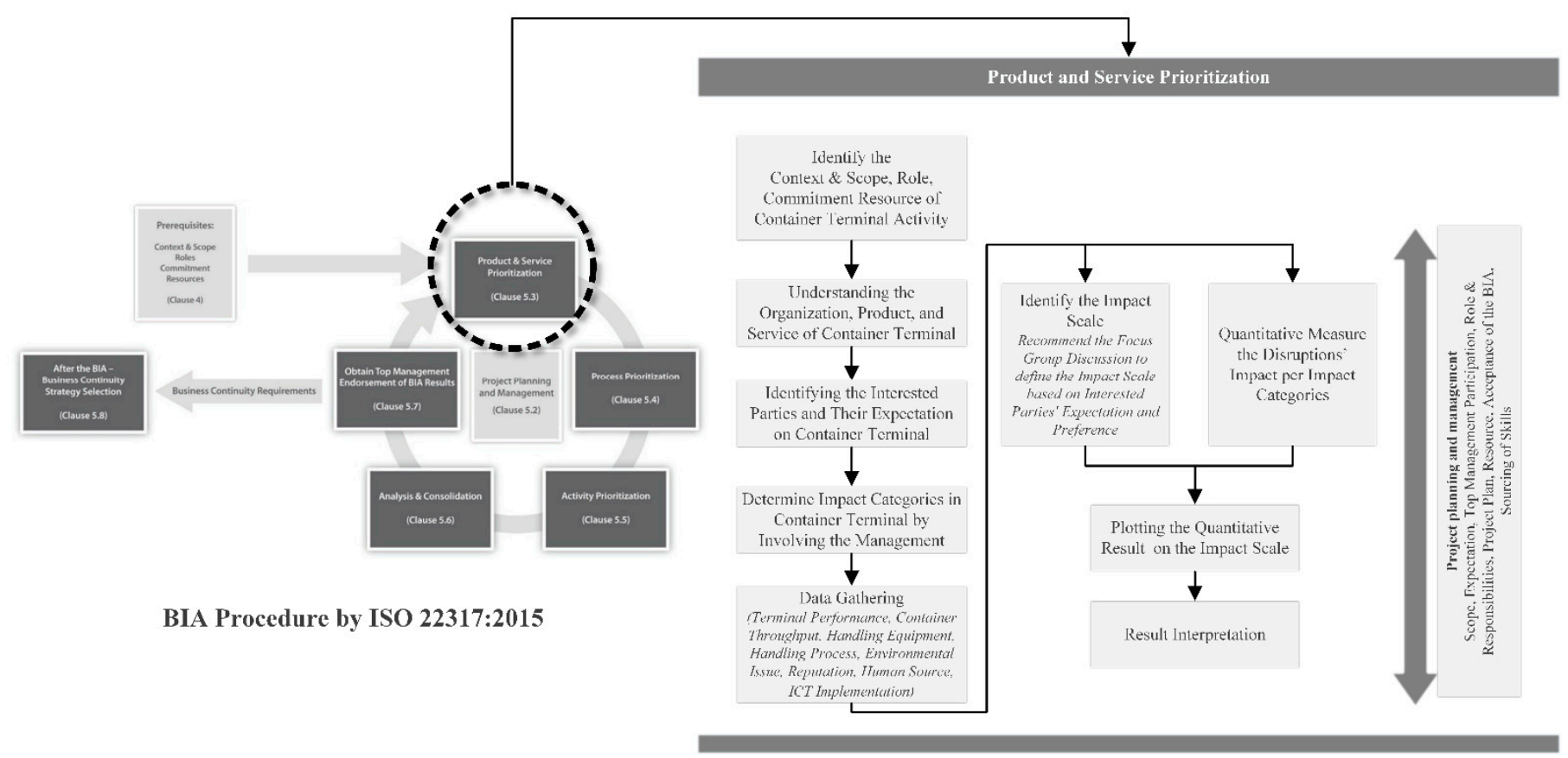

Figure 2. BIA material deepening with application in container terminals.

\subsection{Define the Impact Category}

To identify the impact categories, we started with a survey of the interested parties at Container Terminal $X$ to map the categories of impacts on disruption and determine the scale of the impacts. As recommended by ISO 22031, and as explained by Olander (2006), the interested parties selected in the business impact analysis survey were individuals who are closely related to the business continuity management system, who can lead, or are affected by, the goal of the corporation or business [11,27]. The interested parties selected in this study were from the middle to top management level in operational, financial, commercial, public relations, and human resources affairs. Impact preferences were determined by considering the company's vision and mission, current business position, and business state in the future.

After mapping the impact categories of a disruption that occurred, the study continued with a quantitative analysis of each impact category using a history of port performance in conditions before and after the disruption occurred. For the impact of decreased productivity, the analysis was carried out based on the decrease in port utility due to port equipment stoppage. In the category of economic loss impact, the data analyzed were the reduction in the number of containers that could be handled. In the category of the impact of a decrease in employee productivity, the data analyzed were lost work time due to the inoperability of administrative equipment. In the category of decreased numbers of customers, the data analyzed were the decrease in ship arrivals per day after the disruption occurred. In the category of the impact of a decline in company reputation, public assessments and media coverage of port performance was the basis of the analysis. In the category of the impact of wasted energy, the data analyzed were the wasted energy spent to reactivate electrical equipment after the electrical system had been repaired. The results of the quantitative analysis on the disruption impact category were then mapped back to the impact category 
level scale obtained during the survey. This mapping was able to conclusively reveal how disruption can have a substantial and measurable impact on port business continuity.

\subsection{Quantitative Impact Assessment Method}

To quantitatively measure the impact of electrical distribution events on the container terminal, we referred to several supporting articles. To find out what the equation of productivity after a disruption is, we referred to the Kullstam equation, which states that system availability is the time between two failure events minus the maintenance and repair time [28], and then related the results to the productivity of a container terminal as measured by the operating time at the terminal [29].

According to Novati (2015), and Oztanriseven and Nachtmann (2017), to measure the economic impact of an event, a container terminal revenue description is generally used as a parameter from the business and financial side [22,25]. For the container terminal considered in this study, the company's revenue could be represented by a decrease in the flow of containers, which was the most considerable portion of revenue for the container terminal. Equation (1) presents the existing equations derived from the research publications of Oztanriseven and Nachtmann (2017).

$$
\Lambda_{i}(t)=\left(\frac{f_{i}^{1}(t)}{B_{i} N_{i} \Theta(t)}\right) \forall i \varepsilon I ; \forall i \varepsilon T
$$

$\Lambda_{i}(t)$ : Average number of commodity $i$ shipments per day in year $t$;

$f_{i}^{1}(t)$ : Flow of commodity $i$ by mode of transportation $q$ in year $t$;

$B_{i}$ : Capacity of a barge carrying commodity $i$;

$N_{i}$ : Number of barges per shipment of commodity $i$;

$\Theta(t)$ : Number of working days without a disruption in year $t$.

The management states employee productivity was also a parameter that needed to be measured as it is known to impact productivity and company finances. According to Collewet and Sauermann (2017), employee productivity can be measured using working hours [30]. In electrical disruption, unproductive working hours are measured when employees cannot use computers and communication equipment to complete their administrative tasks.

On the basis of the research conducted by Jain and Winner (2013), it is known that reputation can be measured by the news in the mass media since the media is a communication tool that can form a public perspective of the condition of a company [31,32]. To measure the decline in the company's reputation, we tracked media coverage of disruptions in local, national, and international media.

To measure the decrease in the number of customers, we used the number of ship arrivals as a parameter of the impact of an electrical disruption incident. In previous research conducted by Dowd (1990) and Cohen (2002), ship arrivals were closely related to the productivity level of a container terminal $[16,29]$.

Container Terminal $\mathrm{X}$ is a container terminal developed with the green energy concept by limiting fossil fuels and maintaining energy efficiency. Therefore, in terms of its management, wasted energy is one of the company's concerns. According to He, Huang, and Yan (2015) and Wilmsmeier and Spengler (2016), the wasted energy rate can be measured using energy consumption and productivity $[33,34]$. In conditions of electrical disruption in a container terminal, unproductive energy appears when the container crane is restarted, which causes an increase in starting power that is $3-5$ times higher than the normal operating power. Table 1 shows a list of the impacts of the disruption, the equations and parameters used, and the reference sources. 
Table 1. Quantitative calculation based on impact category.

\begin{tabular}{cccc}
\hline No. & Impact Category & Equation/Parameter & References \\
\hline 1 & Decrease in Productivity & $\frac{O P}{(T H-T O)} \times 100 \%$ & Kullstam, 1981 [26] \\
Dowd, 1990 [27] \\
Novati, 2015 [21]
\end{tabular}

\section{Empirical Study}

This study consisted of two parts, including survey activities to determine impact categories and their scale and quantitative calculations to determine the magnitude of the impact arising from the electrical disruption in the Container Terminal X. The survey activity was carried out in two sub-parts; the first sub-parts focused on determining the impact category through questionnaires and interviews, while the second survey was conducted to engage the management of Container Terminal $\mathrm{X}$ in a discussion in order to obtain an agreement on all mutually agreed impacts according to management preferences. Quantitative analysis activities to determine the impact of a description on each impact category were undertaken using performance data from Container Terminal X obtained before and after a disruption occurred.

\subsection{Initial Interview and Impact Scale}

The exploratory process of analyzing the impact caused by electrical disruptions at the container terminal started with interviews with the management, which consisted of operational, financial, and commercial sections. The information explored at this stage was the impact category. The respondents involved in this survey were 30 individuals whose roles influenced both daily business activities and business planning in the long term, such as commissioners, directors, and managers from various departments. In this survey, the interested parties were asked questions in two stages. The first stage involved the interested parties being asked several questions about which impacts would affect the running of the business in Container Terminal X. The prioritized impact categories and the parameters measured in the business impact analysis were impact categories with higher rates of affirmative answers than negative answers. As a form of validation, the results were then reconciled with management to agree on which parameters would be used in the business impact analysis. Table 2 shows a sample of some of the questions asked to respondents in relation to the exploration of the impacts of different categories.

From the several potential categories, the impact categories were narrowed down to six major categories, i.e., decrease in productivity, economic loss, decrease in employee productivity, decrease in the number of customers, decline in company reputation, and wasted energy. The list of impact categories for electrical disruption in the container terminal, established on the basis of the interview results, is shown in Figure 3.

After the impact category was obtained, the interview explored the impact scale for each impact category as the second stage. Interviews were conducted with the same respondents. The exploration aimed to determine the scale of the impact caused by category on the expectations of container terminal management. The second phase of the survey was conducted through focus group discussions involving the management of Container Terminal $\mathrm{X}$. The agreement was made considering the company's vision and mission, risk and impact preferences, current business position, and long-term business plans. Table 3 
shows a list of impact scales compiled from the interviews with the container terminal management personnel.

Table 2. Sample of questions asked to respondents.

\begin{tabular}{|c|c|c|c|c|c|}
\hline \multirow{2}{*}{ Question List } & \multirow{2}{*}{ Respondents } & \multicolumn{2}{|c|}{ Answer (Yes) } & \multicolumn{2}{|c|}{ Answer (No) } \\
\hline & & Respondents & $(\%)$ & Respondents & $(\%)$ \\
\hline Did the decrease in productivity affect the business? & 30 & 27 & $90 \%$ & 3 & $10 \%$ \\
\hline Did the economic loss affect the business? & 30 & 21 & $70 \%$ & 9 & $30 \%$ \\
\hline $\begin{array}{l}\text { Did the decrease in employee productivity affect the } \\
\text { business? }\end{array}$ & 30 & 24 & $80 \%$ & 6 & $20 \%$ \\
\hline $\begin{array}{l}\text { Did the decrease in the number of customers affect the } \\
\text { business? }\end{array}$ & 30 & 18 & $60 \%$ & 12 & $40 \%$ \\
\hline $\begin{array}{l}\text { Did the decline in company reputation affect the } \\
\text { business? }\end{array}$ & 30 & 21 & $70 \%$ & 9 & $30 \%$ \\
\hline
\end{tabular}

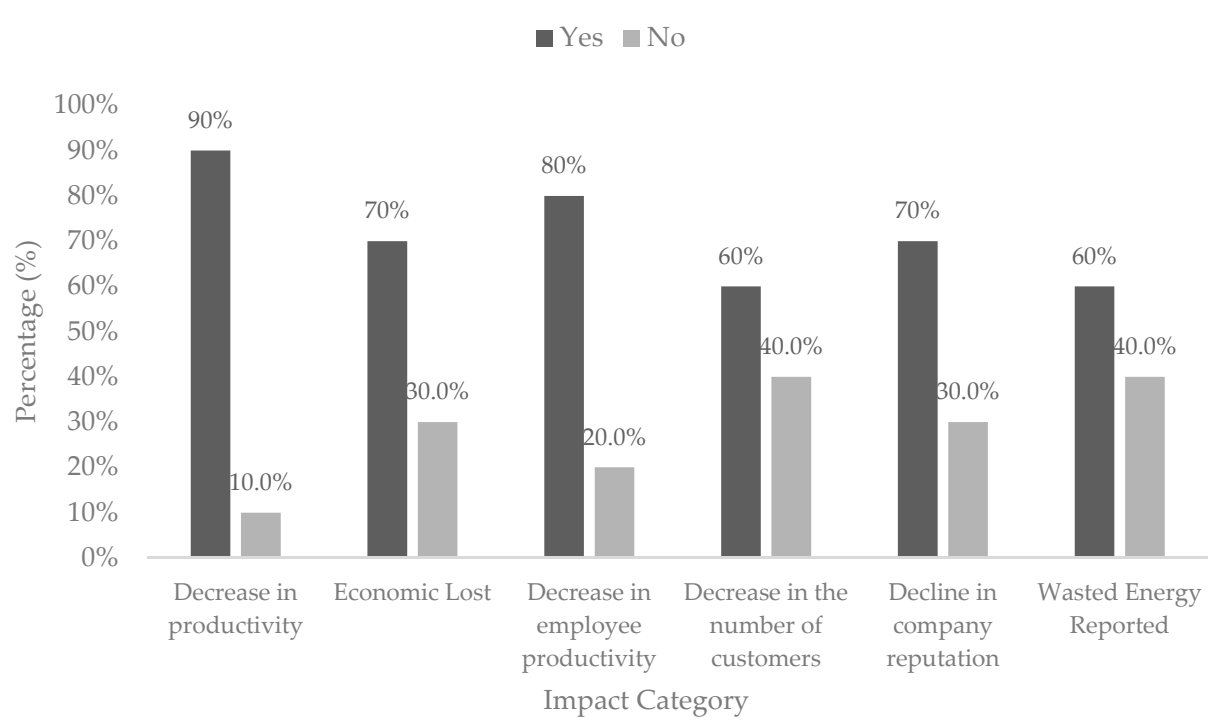

Figure 3. Six categories of potential disruptive impacts.

Table 3. Impact categories and level of impact as indicated by the container terminal management personnel.

\begin{tabular}{|c|c|c|c|c|c|c|}
\hline \multirow[b]{2}{*}{$\begin{array}{l}\text { Level of } \\
\text { Impact }\end{array}$} & \multicolumn{6}{|c|}{ Impact Categories } \\
\hline & $\begin{array}{l}\text { Productivity of } \\
\text { Loading and } \\
\text { Unloading }\end{array}$ & Economic Lost & $\begin{array}{l}\text { Decrease in } \\
\text { Employee } \\
\text { Productivity }\end{array}$ & $\begin{array}{l}\text { Decrease in the } \\
\text { Number of } \\
\text { Customers }\end{array}$ & $\begin{array}{l}\text { A Decline in } \\
\text { Company } \\
\text { Reputation }\end{array}$ & Wasted Energy \\
\hline Insignificant & $\begin{array}{l}\text { Potential } \\
\text { decrease in } \\
\text { loading/ } \\
\text { unloading } \\
\text { productivity to } \\
98-99 \% \text { relative } \\
\text { to the normal } \\
\text { condition }\end{array}$ & $\begin{array}{c}\text { Potential } \\
\text { decrease in } \\
\text { income to } \\
98-99 \% \text { relative } \\
\text { to normal } \\
\text { conditions }\end{array}$ & $\begin{array}{l}\text { Decrease in } \\
\text { employee } \\
\text { productivity } \\
<7 \% \text { from the } \\
\text { ideal condition }\end{array}$ & $\begin{array}{c}\text { Decrease in } \\
\text { ship arrivals by } \\
1 \text { to } 2 \text { ships }\end{array}$ & $\begin{array}{c}0 \text { to } 20 \% \\
\text { No negative } \\
\text { coverage in one } \\
\text { local media }\end{array}$ & $\begin{array}{c}\text { No wasted } \\
\text { energy reported }\end{array}$ \\
\hline Minor & $\begin{array}{l}\text { Potential } \\
\text { decrease in } \\
\text { loading/ } \\
\text { unloading } \\
\text { productivity to } \\
96-98 \% \text { relative } \\
\text { to the normal } \\
\text { condition }\end{array}$ & $\begin{array}{c}\text { Potential } \\
\text { decrease in } \\
\text { income to } \\
96-98 \% \text { relative } \\
\text { to normal } \\
\text { conditions }\end{array}$ & $\begin{array}{l}\text { Decrease in } \\
\text { employee } \\
\text { productivity } \\
7-10 \% \text { from the } \\
\text { ideal conditions }\end{array}$ & $\begin{array}{l}\text { Decrease in } \\
\text { ship arrivals by } \\
2 \text { to } 4 \text { ships }\end{array}$ & $\begin{array}{l}0 \text { to } 20 \% \\
\text { Negative } \\
\text { coverage in } \\
\text { some local } \\
\text { media }\end{array}$ & $\begin{array}{l}<250 \mathrm{kWh} \\
\text { /year }\end{array}$ \\
\hline
\end{tabular}


Table 3. Cont.

\begin{tabular}{|c|c|c|c|c|c|c|}
\hline \multirow[b]{2}{*}{$\begin{array}{l}\text { Level of } \\
\text { Impact }\end{array}$} & \multicolumn{6}{|c|}{ Impact Categories } \\
\hline & $\begin{array}{l}\text { Productivity of } \\
\text { Loading and } \\
\text { Unloading }\end{array}$ & Economic Lost & $\begin{array}{l}\text { Decrease in } \\
\text { Employee } \\
\text { Productivity }\end{array}$ & $\begin{array}{l}\text { Decrease in the } \\
\text { Number of } \\
\text { Customers }\end{array}$ & $\begin{array}{l}\text { A Decline in } \\
\text { Company } \\
\text { Reputation }\end{array}$ & Wasted Energy \\
\hline Moderate & $\begin{array}{c}\text { Potential } \\
\text { decrease in } \\
\text { load- } \\
\text { ing/unloading } \\
\text { productivity to } \\
94-96 \% \text { relative } \\
\text { to the normal } \\
\text { condition }\end{array}$ & $\begin{array}{c}\text { Potential } \\
\text { decrease in } \\
\text { income to } \\
\text { 94-96\% relative } \\
\text { to normal } \\
\text { conditions }\end{array}$ & $\begin{array}{l}\text { Decrease in } \\
\text { employee } \\
\text { productivity } \\
11-14 \% \text { from } \\
\text { the ideal } \\
\text { conditions }\end{array}$ & $\begin{array}{c}\text { Decrease in } \\
\text { ship arrivals by } \\
4 \text { to } 6 \text { ships }\end{array}$ & $\begin{array}{l}0 \text { to } 20 \% \\
\text { Negative } \\
\text { coverage in } \\
\text { regional media }\end{array}$ & $\begin{array}{c}250- \\
500 \mathrm{kWh} / \text { year }\end{array}$ \\
\hline Major & $\begin{array}{c}\text { Potential } \\
\text { decrease in } \\
\text { load- } \\
\text { ing/unloading } \\
\text { productivity to } \\
\text { 92-94\% relative } \\
\text { to the normal } \\
\text { condition }\end{array}$ & $\begin{array}{c}\text { Potential } \\
\text { decrease in } \\
\text { income to } \\
\text { 92-94\% relative } \\
\text { to normal } \\
\text { conditions }\end{array}$ & $\begin{array}{l}\text { Decrease in } \\
\text { employee } \\
\text { productivity } \\
15-18 \% \text { from } \\
\text { the ideal } \\
\text { conditions }\end{array}$ & $\begin{array}{l}\text { Decrease in } \\
\text { ship arrivals by } \\
6 \text { to } 8 \text { ships }\end{array}$ & $\begin{array}{c}0 \text { to } 20 \% \\
\text { Negative } \\
\text { coverage in } \\
\text { national media }\end{array}$ & $\begin{array}{c}500- \\
1000 \mathrm{kWh} / \text { year }\end{array}$ \\
\hline Catastrophic & $\begin{array}{l}\text { Potential } \\
\text { decrease in } \\
\text { load- } \\
\text { ing/unloading } \\
\text { productivity to } \\
\text { below } 92 \% \\
\text { relative to the } \\
\text { normal } \\
\text { condition }\end{array}$ & $\begin{array}{l}\text { Potential } \\
\text { decrease in } \\
\text { income to } \\
\text { below } 92 \% \\
\text { relative to } \\
\text { normal } \\
\text { conditions }\end{array}$ & $\begin{array}{l}\text { Decrease in } \\
\text { employee } \\
\text { productivity } \\
>18 \% \text { from the } \\
\text { ideal conditions }\end{array}$ & $\begin{array}{l}\text { Decrease in } \\
\text { ship arrivals } \\
\text { above } 10 \text { ships }\end{array}$ & $\begin{array}{c}0 \text { to } 20 \% \\
\text { Negative } \\
\text { coverage in } \\
\text { international } \\
\text { media }\end{array}$ & $>1000 \mathrm{kWh} /$ year \\
\hline
\end{tabular}

\subsection{Decrease in Productivity}

In calculating the decrease in productivity at the Container Terminal $X$, the required variables were operating time, length of time that the equipment could be used in one month, maintenance time, and the duration of the disruption. The equipment used to load and unload the containers were ships that stored cranes. This study continued with data collection using questionnaires and interviews with engineering and electrical operations experts at the container terminal. We used this parameter to compare the utility that occurred before and after the disruption in the same month. Table 4 shows the parameters used to measure the changes in productivity of Container Terminal X.

Table 4. Parameters used to measure the decrease in productivity.

\begin{tabular}{cccc}
\hline Description & Symbol & Score & Reference \\
\hline Operating time & OP & $355.9 \mathrm{~h}$ per month & Actual average monthly uptime \\
Total time per month & TH & $730 \mathrm{~h}$ per month & $365 \times 24 \mathrm{~h} / 12 \mathrm{month}$ \\
Corrective maintenance time & CM & $0.83 \mathrm{~h}$ per month & Actual average time of corrective maintenance \\
Preventive maintenance time & PM & $9.09 \mathrm{~h}$ per month & Actual average time of preventive maintenance \\
Disruption duration & W & $18 \mathrm{~h} /$ event & Actual time from disruption until the normal condition \\
Disruption frequency & O & 4 times per year & Highest disruption in one year \\
\hline
\end{tabular}

In this case, if there was no disruption, the information could be written as $U R_{1}$. Then, a second calculation was performed involving the duration of the disruption, written as $U R_{2}$. These two calculations were used to measure the impact of the disruption. Equations (2) and (3) show the utility before and after disruption, respectively. 
The process used to obtain the results of the first utility calculation as the ideal utility can be seen below:

a. Utility before disruption

$$
\begin{gathered}
\left(U R_{1}\right)=\frac{O P}{(T H-T O)} \times 100 \% \\
=\frac{O P}{(T H-(C M+P M))} \times 100 \% \\
=\frac{355.9}{(730-(0.83+9.09))} \times 100 \% \\
=0.4943 \times 100 \% \\
=49.43 \%
\end{gathered}
$$

b. Utility after disruption

$$
\begin{gathered}
\left(U R_{2}\right)=\frac{O P-W}{(T H-T O)} \times 100 \% \\
=\frac{O P-W}{(T H-(C M+P M))} \times 100 \% \\
=\frac{355.9-18}{(730-(0.83+9.09))} \times 100 \% \\
=0.4692 \times 100 \% \\
=46.92 \%
\end{gathered}
$$

Then, a calculation was carried out to establish the decrease in utility in order to assess the type of consequences caused by the impact of disruption to the electricity supply at the container terminal (Equation (4)).

c. Utility Difference

$$
(\% U R)=\frac{U R_{2}}{U R_{1}}=94.94 \%
$$

Disruption in the electricity distribution caused the crane to not be operable, and the loading and unloading of containers therefore stopped. The calculation results show that the occurrence of electrical disruption for $18 \mathrm{~h}$ within one month caused a decrease in loading and unloading productivity to $94.94 \%$ at the container terminal as compared to normal conditions.

\subsection{Economic Lost}

The decrease in revenue was one of the parameters that was considered essential in terms of measuring the impact of a disruption event. Several previous studies used a decline in income as the basis for measuring the conditions before and after the event occurred [21,24]. To measure the decrease in revenue caused by electricity distribution events at the container terminal, we used the container throughput data to represent the company's revenue loss. In the calculation process, we used several parameters: container throughput in April 2020, the length of the disruption time, the average container handling speed per hour, and the number of cranes used during the loading and unloading process. Table 5 below shows the data used to calculate the economic loss of the Container Terminal $\mathrm{X}$ due to electrical disruption.

The calculations determined the percentage decrease in container throughput in the event of an electrical disruption (Equation (5)). This study used the container throughput before disruption as the ideal value, namely the percentage of $100 \%$ as a benchmark for $B I_{1}$ decline. Below is the method for calculating $\mathrm{BI}_{2}$ :

Percentage of container throughput after disruption.

$$
\begin{gathered}
\left(B I_{2}\right)=\frac{C T_{1}-(B \times n \times W)}{C T_{1}} \times 100 \% \\
=\frac{49,160-(17 \times 10 \times 18)}{44,160} \times 100 \% \\
=\frac{49,160-(3060)}{44,160} \times 100 \% \\
=\frac{46,100}{49,160} \times 100 \% \\
=93.78 \%
\end{gathered}
$$


Table 5. Parameters in income reduction calculation.

\begin{tabular}{cccc}
\hline Description & Symbol & Score & Reference \\
\hline Container Throughput in April 2020 & $C T_{1}$ & $49,160 \mathrm{box}$ & $\begin{array}{c}\text { Port performance history } \\
\text { Disruption Time }\end{array}$ \\
Average Number of Container & Actual time from disruption until the normal & condition \\
Handling per-hour & $B$ & $18 \mathrm{~h}$ & Average actual handling speed \\
Unit of STS & $n$ & 10 units & Number of cranes available at the Terminal \\
\hline
\end{tabular}

As a result of the stoppage of loading and unloading activities for $18 \mathrm{~h}$, the container terminal experienced a decrease in container flow revenue equivalent to the value of 3060 box containers; in other words, the percentage of container throughput dropped to $93.78 \%$ of the throughput expected under normal conditions.

\subsection{Decrease in Employee Productivity}

To calculate employee productivity, the variables used were the ideal employee working time and the time of disruption $[30,35]$. This impact calculation was used to measure the decline in employee productivity after the disruption of the electricity supply. We used this equation to compare the employee's time before and after the disruption. Thus, we could find deviations in the percentage of employee productivity. Table 6 shows the parameters of the decline in employee productivity of Container Terminal X due to electrical disruption.

Table 6. Parameters relating to the decrease in employee productivity.

\begin{tabular}{cccc}
\hline Description & Symbol & Score & Reference \\
\hline Working hours in a day & $J$ & $8 \mathrm{~h}$ & The normal working hours in a day \\
Working days in a month & $H$ & 20 Days & $\begin{array}{c}\text { Normal working days in a month } \\
\text { Actual time from disruption until the normal } \\
\text { condition resumed }\end{array}$ \\
\hline
\end{tabular}

Using the above parameters, we obtained the ideal number of employee working hours without disruption, and the number of hours when employees were disrupted. The results of the productivity calculation are shown in Equation (6).

a. Working Hours

$$
\begin{gathered}
(W h)=J \times H \\
=8 \times 20 \\
=160
\end{gathered}
$$

The results showed that the expected working time without the presence of disruptions (ideal productivity) was $160 \mathrm{~h}$ in one month. This result was then used as the highest percentage, which was $100 \%$, to be used as a reference. Later, this value was compared with the productivity percentage in the event of disruption using Equation (7).

b. Productivity after disruption

$$
\left(I P_{2}\right)=\frac{(J \times H)-W}{W h}=\frac{(8 \times 20)-18}{160}=88.75 \%
$$

Then, a calculation was carried out using Equation (8) to establish the decrease in productivity caused by the impact of electricity disruption.

c. Decrease in productivity

$$
\begin{gathered}
(\Delta I P)=I P_{2}-I P_{1} \\
=88.75 \%-100 \% \\
=-11.25 \%
\end{gathered}
$$


The decrease in employee productivity was also found to be the result of an impact that was considered to have been caused by electrical disruption, especially for the container terminals that utilized information technology in order to carry out administrative and financial activities. The interruption of the electric power caused a stoppage in operational activities. Based on the above calculation, it can be seen that there was a decrease of $11.25 \%$ in relation to the ideal condition $(100 \%)$.

\subsection{Decrease in the Number of Customers}

Dowd and Leschine (1990) and Cohen (2002) explained that the number of customers is one of the parameters used to measure a port's productivity. The decrease in the number of customers can be reflected by ship arrival data before and after the disruption. In this study, the data sought were the number of ships that arrived within 10 days of the occurrence of electrical disruption, two days before the occurrence of electrical disruption, on the day of the disruption, and seven days after. Figure 4 shows data on the decline in ship arrivals within a 10-day period. The graph shows a decrease from the period before the disruption to 7 days after the disruption. However, the impact was insignificant, with the decrease being for the number of vessels on the 4th day after the disruption. Figure 4 shows the decrease in the number of customers (ship-calls per day).

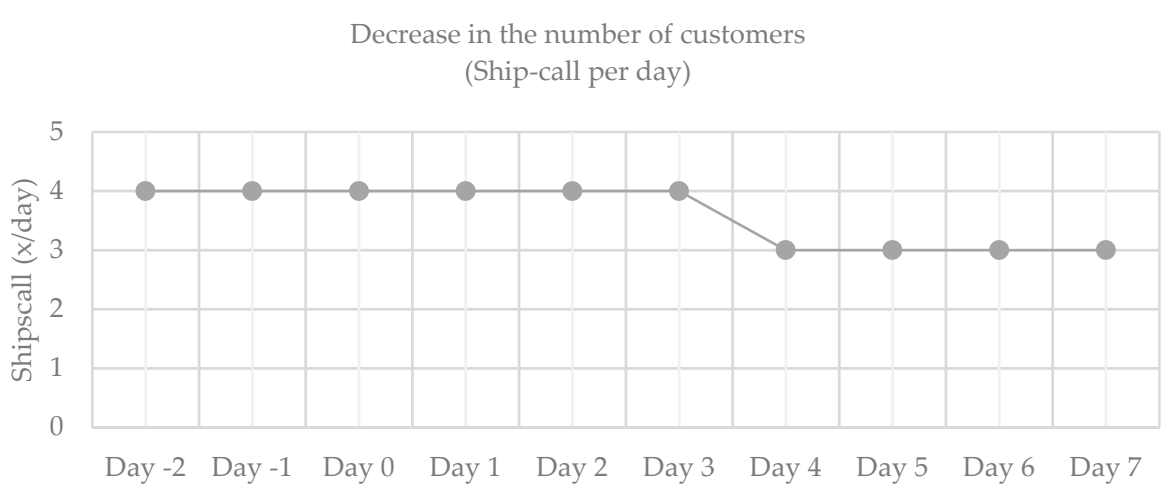

Figure 4. Decrease in the number of customers (ship-calls per day).

\subsection{A Decline in Company Reputation}

In calculating the decline in company reputation in the post-disruption period, we used a questionnaire and recruited experts who have a background in marketing to provide an assessment. The perspective that we measured was the company's perceived reputation, scored as a percentage from 100 to $0 \%$. The questionnaire functioned as an impact assessment of reputation as measured during the periods ten days prior to electrical disruption, two days before the electrical disruption occurred, the day the disruption occurred, and seven days after.

On days one and two before the disruption, the company's reputation was at a percentage of $86.75 \%$, which already indicates reputational damage. However, there was a drastic decrease of $28.25 \%$ on the day of the disruption. On the second day after the disruption, the company reputation index dropped to $50 \%$ and reached a moderate level. However, on the day after the disruption, reputation re-increased on the seventh day.

It can be concluded that the impact of the disruption was highest on the second day following the disruption. Figure 5 shows a decline in company reputation in percentage terms $(\%)$. 


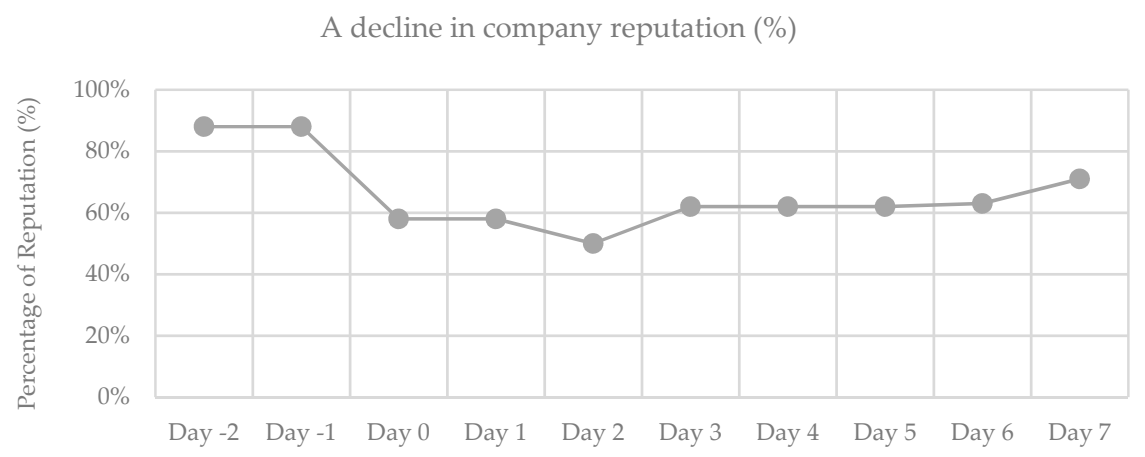

Figure 5. Decline in company reputation (\%).

\subsection{Wasted Energy}

An electrical disruption in a container terminal can cause shutdowns of loading and unloading equipment. When the electricity distribution returns to normal, the equipment will be reactivated with higher power consumption than normally operated. The power needed to reactivate the equipment can become potentially unproductive power since this power should not need to be released if the electricity distribution system is not disrupted.

Table 7 shows the data for wasted energy calculation due to the electrical disruption of Container Terminal X.

Table 7. Parameters for wasted energy calculation.

\begin{tabular}{cccc}
\hline Description & Symbol & Score & Reference \\
\hline Actual power needed to reactivate the equipment & $E$ & $12 \mathrm{kWh}$ & Historical data \\
Number of STS in terminal & $n$ & $10 \mathrm{STS}$ & Number of cranes available at the \\
Frequency of disruptions & $O$ & 4 times/year & Terminal \\
\hline
\end{tabular}

We used Equation (9) to find the amount of energy wasted in one year.

Wasted energy

$$
\begin{gathered}
(W E)=E \times n \times O \\
=12 \times 10 \times 4 \\
=480 \mathrm{kWh} / \text { year }
\end{gathered}
$$

The calculation results show that the energy used to reactivate the 10 STS at the terminal for one year in the event of disruption was 4 (four) times higher than the normal amount, or $480 \mathrm{kWh}$. Based on this calculation, electrical disruption in the container terminal was proven to have an impact in terms of wasted energy. This impact occurred when the port equipment needed to be turned on from the off state. This was the case because electrical equipment, especially electric motors, generally require greater power when starting.

\subsection{Level of the Impact of Disruption on the Management Scale}

After obtaining the results from the list of potential impacts arising from an electrical disruption at the container terminal, the next step involved comparing the impact results with the level of impact perceived by the container terminal management personnel. Table 8 shows the impact of disruption on the management scale. The electricity disruptions had a significant impact in terms of the economic loss category, reaching a catastrophic level. The impact on the potential for decreased loading and unloading productivity, decreased employee productivity and decreased reputation, and wasted energy was at a moderate level. In contrast to the list of other categories, the potential decline in customers due to disruption was still insignificant. The ship owners tended to wait for the terminal to 
re-operate rather than look for a replacement due to issues relating to the availability of other terminals and also because of costs.

Table 8. Level of the impact of disruption on the management scale.

\begin{tabular}{|c|c|c|c|c|c|c|}
\hline \multirow[b]{2}{*}{$\begin{array}{c}\text { Impact } \\
\text { Statement }\end{array}$} & \multicolumn{6}{|c|}{ List of Impacts } \\
\hline & $\begin{array}{l}\text { Productivity of } \\
\text { Loading and } \\
\text { Unloading }\end{array}$ & Economic Lost & $\begin{array}{l}\text { Decrease in } \\
\text { Employee } \\
\text { Productivity }\end{array}$ & $\begin{array}{l}\text { Decrease in the } \\
\text { Number of } \\
\text { Customers }\end{array}$ & $\begin{array}{l}\text { A Decline in } \\
\text { Company } \\
\text { Reputation }\end{array}$ & Wasted Energy \\
\hline Impact result & $\begin{array}{c}\text { Potential } \\
\text { decrease in } \\
\text { B/M } \\
\text { productivity to } \\
94.94 \% \text { relative } \\
\text { to the normal } \\
\text { conditions }\end{array}$ & $\begin{array}{l}\text { Potential } \\
\text { decrease in } \\
\text { income to } \\
93.78 \% \text { relative } \\
\text { to the normal } \\
\text { conditions }\end{array}$ & $\begin{array}{c}\text { Potential } \\
\text { decrease in } \\
\text { employee } \\
\text { productivity } \\
11.25 \% \text { relative } \\
\text { to the normal } \\
\text { conditions }\end{array}$ & $\begin{array}{l}\text { Potential } \\
\text { decrease in the } \\
\text { number of } \\
\text { customers by } \\
\text { one ship }\end{array}$ & $\begin{array}{l}\text { A potential } \\
\text { decline in } \\
\text { company } \\
\text { reputation of } \\
\text { up to } 50 \%\end{array}$ & $\begin{array}{c}\text { Potential } \\
\text { energy wasted: } \\
480 \text { kWh per } \\
\text { year }\end{array}$ \\
\hline Statement & Moderate & Catastrophic & Moderate & Insignificant & Moderate & Moderate \\
\hline
\end{tabular}

\section{Conclusions and Discussion}

Developing a business impact analysis on the port sector, especially a container terminal, often requires a quantitative technical approach as well as consideration of economic impacts.

Therefore, in this study, we deepened the understanding of BIA material, which is still general, into a BIA process that can be applied to the maritime sector, especially in relation to container terminals. The sections detailed in this article identified impact categories, identified impact scales, and quantitatively analyzed impact calculations. In each process, we involved the management of Container Terminal $X$ as interested parties as part of this analysis. In identifying the scale of the impact, the management of Container Terminal $X$ carried out a focus group discussion to establish the impact scale agreement, which was then mutually agreed upon by management as the basis for implementation.

As a result, we obtained six categories of impacts related to electrical disruption of the container terminal, i.e., decreases in productivity, economic loss, decreases in employee productivity, decreases in the number of customers, a decline in company reputation, and wasted energy. These six impact criteria were then analyzed further using quantitative methods to measure the impact generated from each category. In the impact calculation analysis, we used disruption data related to the Container Terminal $X$ for a case study of electricity disruption and used terminal performance data as a calculation database.

Container terminal productivity is a recommended benchmark to reflect the operating conditions of container terminals due to disruption. In this study, loading and unloading productivity at the container terminal was measured as the effectiveness of activities. When the disruption hit, the operating time of the loading and unloading process decreased as long as the equipment could not be operated. To measure the decrease in the efficiency of loading and unloading activities, we used the reduction in operation duration due to disruption as a parameter and then compared it with normal conditions. Based on our calculations, we found that the cessation of electricity supply caused a moderate decrease in productivity.

Economic loss is a parameter that is generally used as a benchmark for most companies to assess the impact and position of the company in terms of the continuation of business operations after the disruption has occurred. In the case of the container terminal, the benchmark of the company's revenue could be assessed using the number of containers that it could handle. Based on the decrease in the number of containers and by referring to the Impact level scale from management, it was found that the distribution of electricity at the container terminal for $18 \mathrm{~h}$ caused economic losses at a catastrophic level.

In the category of decreased employee productivity, we found that the disruption in the container terminal reduced productivity to a moderate level. The limited use of 
computer equipment and other communication tools caused administrative and financial delays, especially at ports that had digitized their activities.

The category of declining company reputation and the scale of energy wasted during electricity disruption in the container terminal showed a moderate impact level. Based on the analysis, we found that the company's reputation decreased by $50 \%$, with the relevant information being sourced from customer ratings and coverage in regional media. Meanwhile, in the category of wasted energy, electrical disruption caused loading and unloading equipment at the container terminal to consume high electrical power during the restarting process. For container terminal management personnel, reputation and energy efficiency were considered essential because the container terminal had the vision to compete with international ports, which prioritize energy efficiency in every activity. Therefore, the decline in reputation and wasted energy became a significant concern.

In the customer decline category, we use the ship arrival parameter to assess conditions after a disruption. In contrast to other categories that show a heavy to catastrophic scale, the decrease in customers of the container terminal in the short term occurred at an insignificant scale because it only experienced a decrease of one ship in ten days. Based on interviews with ship owners, it was found that ship owners tended to wait for the terminal to resume operation rather than looking for another container terminal, considering the lack of availability of replacement containers with the same specifications and the costs incurred by ship owners when changing a terminal.

Based on the study results, it was found that the category that had the most significant results was the impact on economic loss. The impacts that were found to be at moderate levels were wasted energy, declines in the productivity of loading and unloading, decreased employee productivity, and a decline in company reputation. In comparison, one category that was still included in the insignificant category was the decreasing number of customers.

Ultimately, as a component of a company's resilience and sustainability in terms of planning to operate in times of disruption, BIA is a necessary analytical component for organizations. Because the published standard procedures for BIA are still general, BIA can be developed and deepened further by adapting its analysis components to the businesses and activities in which BIA is implemented. Because each business and activity is unique, the work process, targets, and preferences are different, and thus, the implementation of BIA will also be different. The uniqueness of each of these business activities can be an opportunity for academics and practitioners to develop new approaches to the deepening of knowledge on BIA processes. In terms of standardization and publication, so that every BIA can, on the basis of business characteristics, be appropriately recorded and used as a general reference, it is better for BIA recommendations to include derivatives and deepen the scope of BIA based on specific business groups.

Author Contributions: Conceptualization, E.H.B.; methodology, E.H.B.; validation, R.O.S.G., T.P.; formal analysis, E.H.B.; writing — original draft preparation, E.H.B.; writing—review and editing, E.H.B.; supervision, R.O.S.G., T.P. All authors have read and agreed to the published version of the manuscript.

Funding: This research received no external funding.

Institutional Review Board Statement: The study was conducted according to the guidelines, and approved by the Doctoral Program of Marine Technology, Faculty of Marine Technology, Institut Teknologi Sepuluh Nopember, Indonesia.

Informed Consent Statement: Informed consent was obtained from all subjects involved in the study.

Data Availability Statement: The data presented in this study are available on request from the corresponding author.

Acknowledgments: This paper and the research behind it would not have been possible without the exceptional support of from my supervisors, reviewers, editors, and the Container Terminal Company for providing valuable opportunity and data in this study. 
Conflicts of Interest: The authors declare no conflict of interest.

\section{References}

1. Henesey, L.; Notteboom, T.; Davidsson, P. Agent-Based Simulation of Stakeholders Relations: An Approach to Sustainable Port and Terminal Management. In Multi-Agent Systems for Container Terminal Management; Blekinge Institute of Technology: Karlshamn, Sweden, 2003; p. 99.

2. Pant, R.; Barker, K.; Ramirez-Marquez, J.E.; Rocco, C.M. Stochastic Measures of Resilience and Their Application to Container Terminals. Comput. Ind. Eng. 2014, 70, 183-194. [CrossRef]

3. Alyami, H.; Lee, P.T.-W.; Yang, Z.; Riahi, R.; Bonsall, S.; Wang, J. An Advanced Risk Analysis Approach for Container Port Safety Evaluation. Marit. Policy Manag. 2014, 41, 634-650. [CrossRef]

4. Steenken, D.; Voß, S.; Stahlbock, R. Container Terminal Operation and Operations Research-a Classification and Literature Review. OR Spectr. 2004, 26, 3-49.

5. Li, S.; Meng, Q.; Qu, X. An Overview of Maritime Waterway Quantitative Risk Assessment Models. Risk Anal. Int. J. 2012, 32 , 496-512. [CrossRef]

6. Paul, S.K.; Asian, S.; Goh, M.; Torabi, S.A. Managing Sudden Transportation Disruptions in Supply Chains under Delivery Delay and Quantity Loss. Ann. Oper. Res. 2019, 273, 783-814. [CrossRef]

7. Parise, G.; Parise, L.; Pepe, F.M.; Ricci, S.; Su, C.L.; Chavdarian, P. Innovations in a Container Terminal Area and Electrical Power Distribution for the Service Continuity. In Proceedings of the 2016 IEEE/IAS 52nd Industrial and Commercial Power Systems Technical Conference (I CPS), Detroit, MI, USA, May 2016; pp. 1-6.

8. Ghiasi, M.; Irani Jam, M.; Teimourian, M.; Zarrabi, H.; Yousefi, N. A New Prediction Model of Electricity Load Based on Hybrid Forecast Engine. Int. J. Ambient Energy 2019, 40, 179-186. [CrossRef]

9. Mai, T.; Steinberg, D.; Logan, J.; Bielen, D.; Eurek, K.; McMillan, C. An Electrified Future: Initial Scenarios and Future Research for US Energy and Electricity Systems. IEEE Power Energy Mag. 2018, 16, 34-47. [CrossRef]

10. Hiles, A. Business Continuity Management: Global Best Practices; Rothstein Publishing: Brookfield, CT, USA, 2014; ISBN 978-1931332-83-5.

11. ISO 22301: 2019 Security and Reslilience—Business Continuity Management Systems—Requirements. 2019. Available online: https:/ / www.iso.org/standard/75106.html (accessed on 28 August 2021).

12. ISO 22317:2015 Societal Security—Business Continuity Management Systems—Guidelines for Business Impact Analysis (BIA). 2021. Available online: https://www.iso.org/standard/50054.html (accessed on 28 August 2021).

13. Torabi, S.A.; Rezaei Soufi, H.; Sahebjamnia, N. A New Framework for Business Impact Analysis in Business Continuity Management (with a Case Study). Saf. Sci. 2014, 68, 309-323. [CrossRef]

14. Chang, S.E. Disasters and Transport Systems: Loss, Recovery and Competition at the Port of Kobe after the 1995 Earthquake. J. Transp. Geogr. 2000, 8, 53-65. [CrossRef]

15. Chang, S.E.; Falit-Baiamonte, A. Disaster Vulnerability of Businesses in the 2001 Nisqually Earthquake. Glob. Environ. Chang. Part B Environ. Hazards 2002, 4, 59-71. [CrossRef]

16. Cohen, S.S. Economic Impact of a West Coast Dock Shutdown. Univ. Calif. Berkeley 2002, 1, 1-12.

17. Price, W. Reducing the Risk of Terror Events at Seaports 1. Rev. Policy Res. 2004, 21, 329-349. [CrossRef]

18. Hirai, T. The Critical Functionalities of Port Logistics and Its Business Continuity Management. In Proceedings of the 12th Asia Pacific Industrial Engineering \& Management Systems Conference (APIEMS), Beijing, China, 14 October 2011.

19. Ono, K.; Kumagai, K.; Akakura, Y.; Caselli, F. Business Continuity Management System for the Risk Governance in Port Sub-Sector. In Proceedings of the 3rd International Conference on Earthquake Engineering and Disaster Mitigation 2016 (ICEEDM-III 2016), Bali, Indonesia, 1-2 August 2016. Available online: http:/ / hdl.handle.net/2433/225035 (accessed on 28 August 2021).

20. Omer, M.; Mostashari, A.; Nilchiani, R.; Mansouri, M. A Framework for Assessing Resiliency of Maritime Transportation Systems. Marit. Policy Manag. 2012, 39, 685-703. [CrossRef]

21. Rose, A.; Wei, D. Estimating the Economic Consequences of a Port Shutdown: The Special Role of Resilience. Econ. Syst. Res. 2013, 25, 212-232. [CrossRef]

22. Novati, M.; Achurra-Gonzalez, P.E.; Foulser-Piggott, R.; Bowman, G.; Bell, M.G.; Angeloudis, P. Modelling the Effects of Port Disruptions: Assessment of Disaster Impacts Using a Cost-Based Container Flow Assignment in Liner Shipping Networks. In Proceedings of the Transportation Research Board (TRB) 94th Annual Meeting, Washington, DC, USA, 11 January 2015.

23. Wijaya, D.R. Proposed It Financial Management Process Using Itil (It Infrastructure Library) for Port Company in Indonesia. $J$. Theor. Appl. Inf. Technol. 2015, 74, 345-354.

24. Caselli, F.; Beale, M.; Reyes, M. Impact of the Recent Earthquake and Tsunami on Chilean Port. In Geotechnics for Catastrophic Flooding Events; Lai, S., Ed.; CRC Prees: Boca Raton, FL, USA, 2014; p. 207. [CrossRef]

25. Oztanriseven, F.; Nachtmann, H. Economic Impact Analysis of Inland Waterway Disruption Response. Eng. Econ. 2017, 62, 73-89. [CrossRef]

26. Notteboom, T.; Pallis, T. IAPH-WPSP Port Economic Impact Barometer One Year Report: A Survey-Based Analysis of the Impact of COVID-19 on World Ports in the Period April 2020 to April 2021; International Association of Ports and Harbors: Tokyo, Japan, May 2021. Available online: https:/ / sustainableworldports.org/wp-content/uploads/IAPH-WPSP-Port-Economic-ImpactBarometer-20-21-View.pdf (accessed on 28 August 2021). 
27. Olander, S. Stakeholder Impact Analysis in Construction Project Management. Constr. Manag. Econ. 2007, 25, 277-287. [CrossRef]

28. Kullstam, P.A. Availability, MTBF and MTTR for Repairable M out of N System. IEEE Trans. Reliab. 1981, 30, 393-394. [CrossRef]

29. Dowd, T.J.; Leschine, T.M. Container Terminal Productivity: A Perspective. Marit. Policy Manag. 1990, 17, 107-112. [CrossRef]

30. Collewet, M.; Sauermann, J. Working Hours and Productivity. Labour Econ. 2017, 47, 96-106. [CrossRef]

31. Jain, R.; Winner, L.H. Country Reputation and Performance: The Role of Public Relations and News Media. Place Brand. Public Dipl. 2013, 9, 109-123. [CrossRef]

32. Andina-Díaz, A.; García-Martínez, J.A. Reputation and News Suppression in the Media Industry. Games Econ. Behav. 2020, 123, 240-271. [CrossRef]

33. He, J.; Huang, Y.; Yan, W. Yard Crane Scheduling in a Container Terminal for the Trade-off between Efficiency and Energy Consumption. Adv. Eng. Inform. 2015, 29, 59-75. [CrossRef]

34. Wilmsmeier, G.; Spengler, T. Energy Consumption and Container Terminal Efficiency. 2016. Available online: http://hdl.handle. net/11362/40928 (accessed on 28 August 2021).

35. Kjellstrom, T.; Holmer, I.; Lemke, B. Workplace Heat Stress, Health and Productivity-an Increasing Challenge for Low and Middle-Income Countries during Climate Change. Glob. Health Action 2009, 2, 2047. [CrossRef] [PubMed] 